\title{
UTILIZATION OF PLANT SOURCES TO PRODUCE SHERBET
}

\author{
Sofie, Y. EL-Dairy, Neamah, R. Attalla and Eman, F. Mohamed \\ Animal Production Research Institute, Ministry of Agriculture, Dokki, Giza
}

\section{SUMMARY}

Different types of sherbets were manufactured using milk different by-products; permeate, sweet whey and butter milk with the application of slome fruit juices (mango, mandarin and tomato strawberry). Analysis of the mix and resultant sherbets showed that using butter milk increased the specific gravity, weight per/kg. and total solids, while it decreased $\mathrm{pH}$ values, overrun and melting resistant, followed by using sweet whey and permeate respectively compared with control. Using mango, mandarin and tomato strawberry improved the nutritional values of sherbets. Protein was between ( 4.91- 9.03g/100ml), calcium (69.6-183 /ml), potassium (211-367 ml/100ml), phosphorus $(42.8$ - 127.4ml/100ml), iron $(1.13$ $2.56 \mathrm{ml} / 100 \mathrm{ml})$, Zinc $(1.03$ - 2. $12 \mathrm{ml} / 100 \mathrm{ml})$ and energy $(129.69-174.76 \mathrm{~K}$ cal/100g). Fortified sherbets with mango had the highest score followed by tomato strawberry and lastly was mandarin in all treatments.

Keywords: Sherbets, permeate-sweet whey- butter milk- mango, mandarin-tomato strawberry

\section{INTRODUCTION}

Permeate, sweet whey and buttermilk are the most common by- products of dairy industry resulted during production of ultrafiltrated cheese, kareish cheese and butter respectively. The economic and environmental cost for handling these by-products are of an increasing concern for the dairy industry beside the loss of valuable milk nutrients (Ab-Elsalam et al., 2003). The actual of by-products being produced in Egypt are almost four folds of registered quantities. It means that these by products are available in enough quantities and can be utilized as raw materials for some other industries. Recent dietetic recommendations tend to increase the consumption of fruits and vegetables either fresh or by its incorporation in the diet. They are a major source of dietary fibers, minerals and vitamins. In addition, they contribute proteins, fat and carbohydrates.

Most people turned to consume sherbet as a refreshing intake with moderate energy level .Sherbets is a frozen confectionery made from water, milk fat (1-2\%), milk total solids (2-5\%), much lower overrun (25-45\%), higher sugar content(25$35 \%)$.

\section{MATERIAL AND METHODS}

- Nido whole milk

- Sucrose from local super market. 
- Buffalo's permeate sweet whey and butter milk were obtained from. the Unit of Dairy Industry, Dairy Technology Department ,Animal Production Research Institute, Agriculture Research Center, Giza.. - Glucose, Sigma- chemical- Company.

- Apple Pectin.

Fresh juice mango, mandarin and strawberry tomato prepared by using electric

\section{Sherbet mix} blender after removing seeds.

Each 750 of different mixes were prepared as mentioned in Arbuckle (1986) to contain in the final product (sherbet) $25 \%$ sugar, $0.3 \%$ pectin, $25 \%$ Fruit juice mix, $5 \%$ milk solids, $1.3 \%$ milk fat. to give $750 \mathrm{mg}$. using water, milk permeate, sweet whey and butter milk water as control, treatment (1), treatment (2), and treatment (3) respectively. Three control mixes from for the three treatments were prepared individually, heated to $85^{\circ} \mathrm{C}$, cooled and aged to $4^{\circ} \mathrm{C}$ for $24^{\mathrm{h}}$, then frozen in an ice cream freezing machine (Lind \& Polar's 1605, Italy). During freezing, $250 \mathrm{~g}$ of the prepared fruit juices were added individually to each $750 \mathrm{~g}$ mix to give $25 \%$ fruit in the resultant sherbet solution. Citric acid was added to make titratable acidity of the sherbet up to $0.35 \%$ as lactic acid (Arbukle, 1988). Different sherbet treatments were packed in $100 \mathrm{ml}$ cups and hardened at $-18 \mathrm{C}^{\circ}$ in a freezing cabinet according to Rothwell (1976).

\section{Method of analysis}

The different sherbet mixes were analyzed for $\mathrm{pH}$ using $\mathrm{pH}$ meter digital Ionizer model (501 Italy), specific gravity according to Winton (1958), weigh per kilo gram according to Burke (1947), viscosity using Hoppler viscometer type BH2 No 644312 (Bhanumurthi et al., 1972), melting resistance and overrun (Arbuckte, 1986), Organoloptic scoring (Rothwell.1960), protein and ash (O.A.C). fat and total solids (Ling 1963). Minerals: Calcium was determined according to Foulker \& Neites (1982). Phosphorus was determined according to El-Merzabani et al. (1977). Potassium was determined according Sunder Man (1958). Zinc was determined by colorimetric method according to Honsher and Zak (1985).

\section{RESULTS AND DISCUSSION}

\section{Chemical composition}

Data presented in Table (1) shows that the contents of total solids, protein, Fat, ash and minerals in butter milk were higher as compared with those of whey and permeate (Kramsof et al., 1986).

On the other hand; the $\mathrm{pH}$ values, total solids, carbohydrate, potassium and zinc were higher in mango as compared with those of mandarin and tomato strawberry sherbets, while protein, phosphorous and iron were higher in tomato strawberry as compared with those of mango and mandarin. Fruits and vegetables are a vital source of essential minerals, vitamins and dietary Fibers. They are well recognized to supply fair amounts of carbohydrates, proteins and energy (Kadam and Solunkhe, 1995). 
Table 1. Chemical composition of raw materials used in sherbets mixes $(100 \mathrm{ml})$

\begin{tabular}{|c|c|c|c|c|c|c|}
\hline Parameters & Permeate & whey & $\begin{array}{l}\text { Butter } \\
\text { milk }\end{array}$ & Mango & Mandarin & $\begin{array}{c}\text { Strawberry } \\
\text { Tomato }\end{array}$ \\
\hline Total solids/g & 5.8 & 6.42 & 9.00 & 19.5 & 12.03 & 12.8 \\
\hline Protein/g & 0.15 & 0.9 & 3.05 & 0.34 & 0.44 & 1.1 \\
\hline Carbohydrate/g & 4.9 & 4.9 & 4.5 & 17.2 & 12.53 & 6.8 \\
\hline Fat/g & 0.01 & 0.3 & 0.5 & 0.41 & 0.18 & 0.16 \\
\hline Ash/g & 0.5 & 0.61 & 0.7 & 0.43 & 0.32 & 1.1 \\
\hline $\mathrm{pH}$ value & 6.6 & 6.4 & 5.9 & 4.75 & 4.17 & 3.93 \\
\hline Calcium & 38.5 & 51.5 & 108.0 & 165.0 & 37.4 & 8.0 \\
\hline$\stackrel{\infty}{\Xi} \Xi$ Potassium & 126.0 & 142.0 & 150.0 & 180.0 & 131.0 & 243.0 \\
\hline 雪 Phosphorous & 38.0 & 40.1 & $68 . .35$ & 22.5 & 15.55 & 48.3 \\
\hline Iron & 0.05 & 0.072 & 0.1 & 0.42 & 0.39 & 1.51 \\
\hline Zinc & 0.09 & 0.1 & 0.58 & 053 & 0.51 & 0.12 \\
\hline
\end{tabular}

Table (2) showed some increase in specific gravity and weight $/ \mathrm{kg}$ in all treatments as compared to the control, especially when using butter milk with tomato strawberry.

Table 2. Some physiochemical properties of sherbets mixes based on permeate, sweet whey and butter milk

\begin{tabular}{|c|c|c|c|c|c|}
\hline \multirow{2}{*}{ Treatments } & \multirow{2}{*}{$\mathrm{pH}$ value } & \multirow{2}{*}{$\begin{array}{c}\text { Specific } \\
\text { gravity } \mathrm{g} / \mathrm{cm}^{3}\end{array}$} & \multirow{2}{*}{$\begin{array}{c}\text { Weight } \\
\text { (Kg) }\end{array}$} & \multicolumn{2}{|c|}{ Viscosity Cps } \\
\hline & & & & Fresh & After $24^{\mathrm{hr}}$ \\
\hline \multicolumn{6}{|c|}{ Mango } \\
\hline $\mathrm{C}$ & 6.67 & 1.015 & 4.410 & 8.89 & 10.95 \\
\hline 1 & 6.65 & 1.021 & 4.436 & 13.08 & 14.17 \\
\hline 2 & 6.53 & 1.029 & 4.471 & 14.08 & 15.17 \\
\hline 3 & 6.08 & 1.064 & 4.623 & 55.97 & 98.09 \\
\hline \multicolumn{6}{|c|}{ Mandarin } \\
\hline $\mathrm{C}$ & 6.67 & 1.015 & 4.410 & 8.89 & 15.95 \\
\hline 1 & 6.63 & 1.024 & 4.449 & 15.22 & 16.31 \\
\hline 2 & 6.47 & 1.051 & 4.567 & 18.12 & 19.19 \\
\hline 3 & 6.01 & 10.79 & 4.688 & 41.77 & 43.86 \\
\hline \multicolumn{6}{|c|}{ Tomato strawberry } \\
\hline $\mathrm{C}$ & 6.67 & 1.015 & 4.410 & 8.89 & 10.95 \\
\hline 1 & 6.63 & 1.029 & 4.471 & 17.34 & 18.42 \\
\hline 2 & 6.47 & 1.059 & 4.603 & 20.14 & 21.20 \\
\hline 3 & 6.04 & 1.082 & 4.703 & 45.84 & 46.89 \\
\hline
\end{tabular}

Table (2) also revealed that the viscosity increased when using permeate, whey and butter milk respectively. Highest value was reached by using butter milk with mango. This can be attributed to the increase in acidity as reported by Mustafa et al., (2001). Addition of permeate, sweet why and butter milk to different mixes increased viscosity compared with the control. The highest viscosity were in butter milk sherbets mixes due to the $\mathrm{pH}$ values and chemical compositions of butter milk (Sofie et al., 1994). 
Mix properties:

Table (2) indicates the properties of the control mix and 1, 2, 3, mixes before adding fruits into the freezing machine. It could be observed that the $\mathrm{pH}$ values were the highest in all mixes mixed with water, while it were the lowest in all mixes with butter milk. It is due to the decreased $\mathrm{pH}$ values in butter milk. (Shadia et al., 1994).

\section{Physicochemical Properties of the resultant sherbets}

Table (3) outlines the physical properties of sherbets as affected by the addition of fruit juices. The addition of mango, mandarin, tomato strawberry had slightly affected the specific gravity and weight per $\mathrm{kg}$. These results are in agreement with Salem (2003) and Gofour et al, (2007). Data of the same Table, show that sherbet made with sweet whey and tomato strawberry had the highest overrun value while using mango with butter milk led to lowest overrun, this is obviously related to the raw material of different fruits and milk by products (EL-Dairy, 1984). Regarding the rate of melting after $0.5,1$ and 1.5 hours, Tomato strawberry sherbets melt faster then mandarin and mango sherbets. Also, it was clear that the melting rate decreased by using butter milk, control, permeate and sweet whey respectively.

Table 3. Some physiochemical properties of sherbets based on permeate, sweet whey and butter milk

\begin{tabular}{|c|c|c|c|c|c|c|}
\hline \multirow{2}{*}{ Treatment } & \multirow{2}{*}{$\begin{array}{c}\text { Specific } \\
\text { gravityg/(cm }\end{array}$} & \multirow{2}{*}{ Weight/Kg } & \multirow{2}{*}{ Overrun } & \multicolumn{3}{|c|}{ Melting \% } \\
\hline & & & & 30 & 60 & $90 \mathrm{~min}$ \\
\hline \multicolumn{7}{|c|}{ Mango } \\
\hline $\mathrm{C}$ & 0.760 & 3.302 & 42.83 & 1.0 & 7.14 & 14.9 \\
\hline 1 & 0.799 & 3.472 & 44.34 & 1.4 & 9.85 & 15.26 \\
\hline 2 & 0.882 & 3.832 & 49.64 & 0.0 & 10.83 & 16.06 \\
\hline 3 & 0.980 & 4.258 & 37.00 & 0.0 & 3.07 & 9.37 \\
\hline \multicolumn{7}{|c|}{ Mandarin } \\
\hline $\mathrm{C}$ & 0.760 & 3.302 & 43.48 & 4.85 & 44.96 & 76.0 \\
\hline 1 & 0.765 & 3.324 & 46.74 & 5.06 & 49.98 & 91.11 \\
\hline 2 & 0.770 & 3.356 & 50.72 & 7.9 & 57.54 & 95.00 \\
\hline 3 & 0.910 & 3.954 & 39.80 & 1.60 & 2.28 & 31.00 \\
\hline \multicolumn{7}{|c|}{ Tomato strawberry } \\
\hline $\mathrm{C}$ & 0.760 & 3.302 & 46.83 & 15.03 & 52.73 & 80.40 \\
\hline 1 & 0.771 & 3.350 & 48.00 & 16.80 & 62.22 & 96.10 \\
\hline 2 & 0.779 & 3.385 & 53.37 & 18.56 & 68.8 & 98.00 \\
\hline 3 & 0.928 & 4.032 & 42.00 & 8.28 & 26.73 & 30.41 \\
\hline
\end{tabular}

From Table (4) it can be observed that mango sherbets had the highest total solids followed by tomato strawberry and lastly mandarin sherbets. Also, it can be noticed that total solids increased by using permeate whey and butter milk respectively. It was also noticed that using butter milk in sherbets gave the highest values of protein especially when mixed with tomato strawberry, this could be due to the highest protein content in butter milk and tomato strawberry. Data indicated that using mango had the highest values of fat followed by mandarin and lastly tomato Strawberry (Kadam and Salunkhe, 1995). 
Table 4. Chemical composition of sherbets based on permeates, sweet whey and butter Milk

\begin{tabular}{|c|c|c|c|c|c|c|c|c|c|}
\hline \multirow[b]{2}{*}{ Treat. } & \multirow{2}{*}{$\begin{array}{l}\text { Total } \\
\text { solid }\end{array}$} & \multirow{2}{*}{$\begin{array}{l}\text { Protein } \\
\mathrm{g} / 100 \mathrm{ml}\end{array}$} & \multirow{2}{*}{$\begin{array}{c}\text { Fat } \\
\mathrm{g} / 100 \mathrm{ml}\end{array}$} & \multicolumn{5}{|c|}{ Mineral mg/100ml } & \multirow{2}{*}{$\begin{array}{c}\text { Energy } \\
\text { Kcol/ } \\
100 \mathrm{ml}\end{array}$} \\
\hline & & & & Calcium & Phosphorous & Potassium & Iron & Zinc & \\
\hline \multicolumn{10}{|c|}{ Mango } \\
\hline $\mathrm{C}$ & 32.22 & 4.91 & 2.20 & 69.6 & 49.7 & 211.0 & 1.81 & 1.45 & 134.56 \\
\hline 1 & 35.25 & 5.20 & 2.33 & 105.2 & 63.3 & 297.0 & 1.20 & 1.67 & 147.84 \\
\hline 2 & 35.44 & 4.71 & 2.82 & 126.0 & 68.4 & 320.0 & 1.52 & 1.96 & 159.38 \\
\hline 3 & 35.81 & 8.32 & 3.42 & 183.0 & 95.2 & 337.0 & 1.6 & 2.12 & 174.76 \\
\hline \multicolumn{10}{|c|}{ Mandarin } \\
\hline $\mathrm{C}$ & 32.22 & 5.11 & 1.24 & 85.3 & 42.8 & 148.0 & 1.13 & 1.38 & 129.96 \\
\hline 1 & 33.10 & 5.61 & 1.33 & 96.6 & 47.7 & 214.0 & 1.35 & 1.56 & 132.81 \\
\hline 2 & 34.11 & 6.39 & 1.52 & 117.0 & 78.7 & 249.0 & 1.54 & 1.84 & 137.64 \\
\hline 3 & 34.31 & 8.69 & 2.92 & 158.0 & 107.6 & 282.0 & 1.69 & 2.04 & 144.24 \\
\hline \multicolumn{10}{|c|}{ Tomato strawberry } \\
\hline $\mathrm{C}$ & 32.22 & 5.71 & 1.07 & 58.1 & 67.0 & 263.0 & 2.04 & 1.03 & 126.76 \\
\hline 1 & 35.00 & 5.83 & 1.11 & 67.0 & 65.6 & 339.0 & 2.12 & 1.15 & 140.03 \\
\hline 2 & 35.22 & 6.63 & 1.41 & 89.0 & 99.3 & 358.0 & 2.38 & 1.29 & 140.33 \\
\hline 3 & 35.47 & 9.03 & 2.53 & 127.0 & 127.4 & 367.0 & 2.56 & 1.63 & 144.69 \\
\hline
\end{tabular}

Adding permeate, whey and butter milk to fruits we accompanied by high level of calcium, potassium and phosphorous as reported by (Hanaa et al., 2007) and AbdEl Salam et al, (2007). The calcium content in mango sherbets with diary by products had the highest value $(183 \mathrm{mg} / 100 \mathrm{ml})$. the calcium content in mango was higher than that in other fruits being $165.0,37.4,8.0 \mathrm{mg} / 100 \mathrm{ml}$ for mango, mandarin and, tomato strawberry respectively. Studies indicate that calcium is the most abundant mineral in the body and $99 \%$ is found in the Skelton. A basic function of calcium is therefore to provide a strong framework for supporting and protecting delicate organs jointed to allow movement and malleable to allow growth. The addition of by-products to fruits improves the bioavailability of calcium (Kansal, 2002). Phosphorus is the second most abundant minerals in the body and about $80 \%$ is found in bones and teeth. Phosphorus is further involved in the control of appetite, in a manor not yet fully understood in the efficiency of food utilization (Ternouth, 1990). Phosphorus is arguably the meat potent of all the mineral elements. From the obtained results in Table (4) It was noticed that phosphorus content of sherbets varied between $42.8: 127.4 \mathrm{mg} / 100 \mathrm{ml}$, the highest value was recorded with tomato strawberry sherbet with butter milk. On the other hand, potassium is the major intracellular ion in tissues. Many enzymes have specific requirements for potassium and element influences many intracellular resections involving phosphate with effect on enzyme activities and muscle contraction (Using 1960; Thompson, 1972). From the same Table we can observe that mango sherbet with butter milk gained the highest value of potassium. (307 mg/100ml).

Table (4) also shows that tomato strawberry with all by-products had the highest values of iron; Increasing iron content could be attributed to the higher content on raw materials of fruits themselves. The high iron content of these fruits can improve the iron content of sherbets with milk by-products which were considered as poor sources of Fe (Abd-EL-Salam, 2000). Approximately $60 \%$ of body iron is present as hemoglobin. On the other hand mango sherbets with milk by-products had the highest content of zinc. The most important functional property of zinc stand out for 
gene expression and appetite (Cousins, 1997). A number of trace elements (zinc, Fe) and other nutrients are strongly related to adequate immunize response this nutrients act together or separately to form an active immunize response. From Table (4) it could be observed that there is a slightly different in energy between tomato strawberry and mandarin sherbets. While mango sherbets had the highest energy, it is due to the higher content of carbohydrate of mango juice.

Sensory evaluation of different sherbets is recorded in Table (5). Generally it could be observed that mango sherbets with butter milk and tomato strawberry sherbets with butter milk flavors as well as their body and texture were more accepted by panel-tasting members than mandarin. Regarding sherbets with butter milk, flavor and body and texture was somehow heavy due to us higher total solid and melting properties.

Table 5. Sensory evaluation of sherbets based permeate, sweet whey and butter Milk

\begin{tabular}{ccccc}
\hline Treatment & $\begin{array}{c}\text { Flavor } \\
50\end{array}$ & $\begin{array}{c}\text { Body \& texture } \\
40\end{array}$ & $\begin{array}{c}\text { Melting quality } \\
10\end{array}$ & $\begin{array}{c}\text { Total } \\
(100)\end{array}$ \\
\hline C & 43 & Mango & \\
1 & 46 & 37 & 7 & 87 \\
2 & 47 & 39 & 8 & 93 \\
3 & 49 & 40 & 8 & 94 \\
\hline C & 38 & Mandarin & 9 & 98 \\
1 & 44 & 36 & 6 & 80 \\
2 & 45 & 38 & 8 & 90 \\
3 & 46 & 39 & 8 & 91 \\
\hline C & 40 & 9 & 94 \\
1 & 45 & Tomato strawberry & & 91 \\
2 & 46 & 36 & 6 & 92 \\
3 & 48 & 38 & 8 & 96 \\
\hline
\end{tabular}

\section{CONCLUSION}

In conclusion, production of sherbets can be successfully made by using milk byproducts (permeate, sweet whey and butter milk) fortified with mango, mandarin and tomato strawberry. These additives would rather exhibit more nutritional values and health benefits.

\section{REFRENCES}

Abd EL-Salam, M.H., 2000. Nutritive value on milk and milk products (in Arabic). General Book Organization, Cairo, Egypt.

Arbuckle, W.S., 1986. Ice cream. $4^{\text {th }}$ ed. AVI Publishing company Inc. West port, Connecticut, USA.pp.26-259. 
Bhanumurthi, J.L., K.S. Trhon., Y.R. Srinvasan and O. Samlik, 1972. Viscosity changes in sweetened condensed full cream buffalo milk during storage, Indian. J. Dairy Sci., 25:

Burke, A.D., 1947. Practical ice cream making Co. Milwaukee, Wisconsin U.S.A.

EL-Dairy, S.Y.T., 1984. Technological studies on flavored ice milk Ph. D. Ain Shams University Cairo.

El-Merzabani. M.M., A.A. EL-Aaer, and N.L. ZakHari, 1977. Phosphorus colorimetric method. J. clinic. Chem. Clinic. Biochem. 15:517-518.

Foulker, W.R. and S. Meites, 1982. Selected methods for the small clinical laboratory Washington, d. c. b 125.

Gafour. W. A., E.A.Y. Essawy and A.S. Salem, 2007. Incorporation of material antioxidants into ice cream. Egypt. J. Dairy Sic., 35:117-123.

Hanaa H. Elsayed, Shadia A. Freig and Aida S. Salem, 2007. Preparation and evaluation of new functional beverage. Proc. to the Egypt. Conf. Dairy Sci, \&Techn., 211-225.

Kadam, S. S. and Salunkhe, 1995. D. K. Fruits in human nutrition, in handbook of fruit science and technology (D. K. Salunkhe and S. S. Kadan, eds). Marcel Dekker. New York, (1995 P.416).

Kransof, A., K. Poliamskie and K.O.L. Nekteren, 1986. Industries of Dairy byproducts. Pub. Lightly and food Industries, Moscow.

Ling, E.R., 1963. Dairy chemistry Vol. II, practical Chapman and Hall, Ltd, London.

Marshall, R.T. and W.S. Arbuckl, 1996. Ice cream, fifth Edition. Chapman and Hall. Int. Thomson pub.

Mostafa, M.B.M., F.A. Abd-Malek and A.I. Okasha, 2001. Utilization of some dairy by-products in the manufactured of reduced cholesterol frozen yoghurt. Proc. $8^{\text {th }}$ Egypt conf. Dairy Sci and Technol., 551.

Rothwell, J., 1960. Recent ice cream research (1954-1959). Dairy Sci.; Abst.22 (10) 484-486.

Rothwell, J., 1976. Ice cream, its present day manufacture and some problem. J. Society of Dairy Tech. 22(3): 161-166.

Salem. A.S., A.M. Abdel-Salam and S. EL-Shibiny, 2003. Preparation and properties of low fat and low sugar functional ice cream varieties. Egypt. J. Dairy Sci, 31:399.

Shadia A. Fikry, Soad. A. Ibrahim and Sofi.Y. EL-Dairy, 1994. Utilization of sweet butter milk and fresh skim milk in ice milk making, Egypt. J. Dairy Sci, 22:39-46.

Sofie, Y. EL Dairy, Soad A. Ibrahim and Shadia A. Fikry, 1994. Substitution of milk solids not fat with Some by products in making Ice milk Agri. Res. Rev.876-882.

Sundermam, F.W., 1985. Potassium turbid. colourimetric method. Am.., J. Clin. Bathol. 29-95.

Winton, A.L., 1958. Analysis of foods: $3^{\text {rd }}$ Printing P.6. Jon Wiley and sons Inc., New York. 


\section{إستخدام مصادر نباتية فى إنتاج منتجات لبنية مثل Sherbet ذات قيمة غذائية}

\section{صوفى يوسف الديرى، نعمة رائف عطا الله، إيمان فؤاد محمد}

معه بحوث الإتتاج الحيوانس، ونارة النراعة، الدقى ، الجيزة، مصر

$$
\begin{aligned}
& \text { تم إعداد أنواع مختلفة من الشربت بإستخدام كل من راشح تركيز اللبن permeates والشرش الحلو }
\end{aligned}
$$

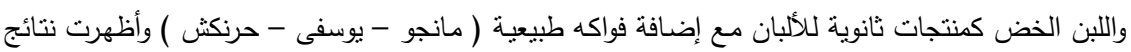

$$
\begin{aligned}
& \text { التحاليل أن هناك زيادة في الكثافة النوعية والوزن النوعي بالكيلوجرام و نسبة الجوامد الكلية بإستخدام اللبن }
\end{aligned}
$$

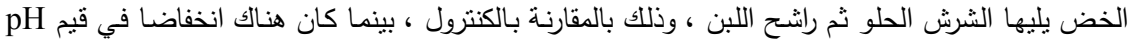

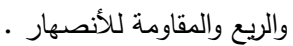

$$
\begin{aligned}
& \text { إستخدام المانجو واليوسفي والحرنكش أدى الى تحسبن القيمة الغذائية للثربت حيث أدى الى زياده في نسية }
\end{aligned}
$$

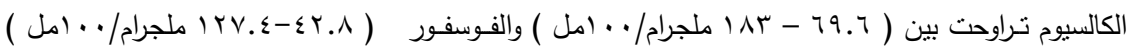

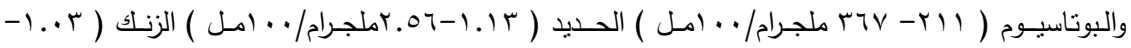

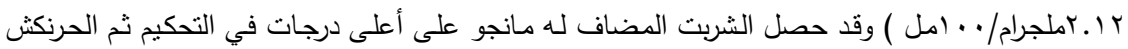

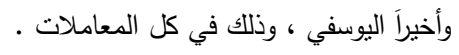

